\title{
Appraisal of Asphalt Concrete with Coal Bottom Ash as Mineral Filler
}

\author{
${ }^{*}$ Ashiru Mohammed, Ibrahim Aliyu, Tasiu A. Sulaiman, Hussaini A. Umar and Yasir Jubril \\ Department of Civil Engineering, Ahmadu Bello University, Zaria, Nigeria \\ ibshazali03@hotmail.com | ibrahimaliyu67@yahoo.com | \{tasiuashirusulaiman | haumar12 | yasirjubril\}@gmail.com
}

Received: 04-MAY-2021; Reviewed: 22-MAY-2021; Accepted: 20-JUN-2021

http://dx.doi.org/10.46792/fuoyejet.v6i2.630

\begin{abstract}
This study was conducted to access the performance of asphalt concrete produced with coal bottom ash as partial replacement of cement in the mineral filler. The Marshal Mix design method of hot mix asphalt (HMA) samples preparation and testing was adopted. Fifteen (15) samples of HMA compacted and used for volumetric and stability testing at a varying percentage of bitumen contents $(5.0,5.5,6.0,6.5$, and $7.0 \%$,) following the Asphalt Institute and Nigeria General Specification for Road and Bridges (NGSRB) approach for determining optimum bitumen content (OBC). An Optimum bitumen content of $5.5 \%$ was obtained and used throughout the study. Another set of 15 samples of the HMA were prepared and compacted at varying percentage replacement of cement with CBA in the order of $15,20,25,30$, and $35 \%$ by volume of cement to determine the optimum dosage of the coal bottom ash that will satisfy the requirements for the strength and durability of wearing course of flexible pavement. The Marshall Stability, flow, and the volumetric properties test results obtained indicated that the samples prepared with $25 \%$ CBA as filler with OBC of $5.5 \%$ satisfied the requirements of the NGSRB for wearing course of flexible pavement. Hence, the addition of up to $25 \%$ CBA by volume of cement in asphalt concrete can reduce the consumption of cement and provide a proper means of CBA disposal.
\end{abstract}

Keywords- Coal Bottom Ash (CBA), Marshal Stability, Marshal Flow, Mineral filler, Optimum Bitumen Content (OBC)

\section{INTRODUCTION}

The rapid growth of coal-fired power plants for power generation has resulted in large production of residual coal ashes in the form of fly ash and coal bottom ash (CBA) (Singh and Siddique, 2013). With the continuous accumulation of the residual ash, its disposal becomes of major concern due to the non-availability of its dumping ground. Hence, its disposal is very costly to the power industries (Mohammed and Karim, 2017). Moreover, with an increase in the cost of natural construction materials such as sand and coarse aggregate, bitumen, and cement, researchers and practitioners in the field of civil Engineering developed an interest in utilizing wastes from agricultural and industrial activities that can serve as substitutes to the natural construction materials.

Coal ash bottom (CBA) has been one of the major sources of industrial waste which have been used as subgrade material in highway constructions (Khan and Ghanesh, 2016; Mohammed and Karim, 2017) and fine aggregate in cement and asphalt concrete (Singh and Siddique, 2016). The utilization of coal ash will not only solve the problems of waste disposal but will also provide economic construction material (Huang, 1990). The hot mix asphalt (HMA) production is capital intensive. Therefore, there is a need for alternative materials that can minimize the production cost of asphalt without compromising its performance in service (Rengarasu et al., 2019). The constituents of hot mix asphalt are bitumen, fine aggregate (sand), coarse aggregate, and cement (as filler material).

\footnotetext{
${ }^{*}$ Corresponding Author

Section D- CIVIL ENGINEERING \& RELATED SCIENCES

Can be cited as:

Mohammed A., Aliyu I., Sulaiman T.A., Umar H.A. and Jubril Y. (2021): Appraisal of Asphalt Concrete with Coal Bottom Ash as Mineral Filler FUOYE Journal of Engineering and Technology (FUOYEJET), 6(2), 105-110. http://dx.doi.org/10.46792/fuoyejet.v6i2.630
}

Researchers reported that filler material plays an essential role in filling the voids between coarser aggregates, and hence increasing the stability, density, and toughness of HMA pavement (Modarres and Rahmanzadeh, 2014; Singh and Bhardwaj, 2020). Cement has been widely used in the production of HMA as filler material because of its high filling characteristics (Shuaibu et al., 2019). The production of cement is costly and causes the greenhouse effect on the environment, (Branger et al., 2015) reported that the production process of ordinary Portland cement (OPC) contributes more than $6 \%$ of the total global warming through carbon dioxide $\left(\mathrm{CO}_{2}\right)$ emission. In an attempt to curtail the effect of global warming due to $\mathrm{CO}_{2}$ emission researchers have been working to search for material that will serve as a cement supplement (Kaura et al., 2016).

Because of this, a considerable number of researchers have worked on a variety of industrial by-products and waste materials such as fly ash (Mistry and Roy, 2016), rice husk ash (Modarres and Rahmanzadeh, 2014), blast furnace slag (Movilla-Quesada et al., 2018), waste foundry sand (Shuaibu et al., 2019), palm kernel shell ash, millet husk ash and kaolin (Tahami et al., 2018), sewage-sludge ash (Tenza-Abril et al., 2015) and (Rengarasu et al., 2019) combine Coal Bottom Ash and Carbonized Rice Husk to study their suitability for use in the production of asphalt concrete and reported positive results. However, studies on the use of CBA as filler in the production of asphalt concrete are rare in the literature, but a considerable study on the incorporation of $\mathrm{CBA}$ as a replacement of cement in mortar and concrete has been reported. Thanaya et al. (2006) investigated the influence of utilizing coal ash in the hot mix and cold mix asphalt as filler. They reported that both mixes containing CBA were suitable for low and medium-traffic pavements. Frías et al., (2012) studied compressive strength of mortar using $\mathrm{CBA}$ as an additive in blended cement. They reported up to $20 \%$ CBA by weight of cement can be used as supplements of cement. 
Armada and Faustino, (2016) conducted a study to evaluate performance of ground $\mathrm{CBA}$ as a partial replacement of cement in concrete. Results revealed that there were no significant changes in the compressive strength of the concrete at $20 \%$ by weight of cement of CBA after 28 days of curing, while at 60 days of curing an of up to $20 \%$ was observed. Jaturapitakkul and Cheerarot, (2003) also reported from their studies that compressive strength of both mortar and concrete incorporated with ground CBA as replacement increases after 90days of curing. This could be as a result of higher formation of hydration resulting from pozzolanic activities of CBA after 28 days of curing. In recent years, cement manufacturing has started using CBA as cement constituents due to its pozzolanic nature (Arabani et al., 2017).

However, this study aims to ascertain the properties of asphalt produced with coal bottom ash as mineral filler. Findings of this study could lead to the extensive use of coal bottom ash in the production of asphalt mix, this will significantly reduce the cost the waste ash disposal to the utility companies as well as reducing the quantity of the CBA from the environment.

\section{Materials AND METHOD}

\subsection{MATERIALS}

The materials used in this study include bitumen, aggregates (Coarse aggregates and fine aggregates), Cement (as filler material), and CBA as a partial replacement of cement. The Bitumen is of grade 60/70 was sourced from Niger State Road Maintenance Agency (NIGROMA). The Coarse aggregate was sourced from a Quarry, along Kaduna -Zaria Road and the Fine aggregate (sharp sand) was obtained from a river within Zaria, Kaduna State, Nigeria. Dangote brand of Portland cement of grade 42.5 was used and it was obtained from an open market within Samaru material. The CBA was obtained from the coal power plant of the Dangote cement factory, Obajana, Kogi State.

\subsection{METHODS}

The methods employed in this study for the experimental tests on the HMA constituent were in accordance with the requirements provided in the relevant codes and specification which includes BS codes and ASTM codes. The tests conducted on all the materials and the results obtained are as highlighted in the following Sub Section

\subsubsection{Test on Aggregates}

The results for the preliminary tests conducted and the standards used on the coarse and fine aggregate are as presented in table 1 . The results show that the aggregates satisfied all codes requirements, therefore the aggregates are suitable for use in the asphalt concrete production.

\subsubsection{Test on Bitumen}

The results of the preliminary tests and the standards used on bitumen are presented in table 2 . The results show that the bitumen is of penetration grade $60 / 70$ and has satisfied all the codes requirements needed for use in the production of asphalt concrete.

\subsubsection{Test on Filler (Cement and CBA)}

The tests results for physical properties of the mineral filler (cement and CBA) are as presented in table 3. The CBA was ground and sieved through sieve 200 to obtain required particles size and chemical oxides of CBA was determined using $X$-ray fluorescence spectrometry (XRF) technique. The result of XRF test is as presented in table 4.0. Based on the chemical oxide composition test result it can observed that alumina + silica + iron oxide have sum up to $66.641 \%$ and the calcium oxide $(\mathrm{CaO})$ is greater than $20 \%$. Hence, the CBA satisfied the requirements for class C pozzolana as specified in ASTM C618 -19.

Table 1. Results of Preliminary Test conducted on Coarse and Fine Aggregates

\begin{tabular}{llll}
\hline Test Conducted & Code Used & Test Result & Code Limit \\
\hline Aggregate Crushing Value (\%) & BS 812 Part 112 & 20 & Max. 25 \\
Aggregate Impact Value (\%) & BS 812 Part 111 & 20.6 & Max. 25 \\
Specific Gravity of Coarse Aggregate & ASTM C127 & 2.70 & $2.55-2.75$ \\
Density of Coarse Aggregate $\left(\mathrm{kg} / \mathrm{m}^{3}\right)$ & ASTM C127 & 1685 & $>1450$ \\
Specific Gravity of Fine Aggregates & ASTM C128 & 2.63 & $2.55-2.75$ \\
Density of Fine Aggregates $\left(\mathrm{kg} / \mathrm{m}^{3}\right)$ & ASTM C127 & 1641.5 & $>1400$ \\
Water Absorption for Coarse Aggregate (\%) & BS 812 Part 2 & 0.46 & $<2$ \\
Water Absorption for Fine Aggregate $(\%)$ & BS 812 Part 3 & 8.62 & $<15$ \\
\hline
\end{tabular}

Table 2. Preliminary Test result on Bitumen

\begin{tabular}{llll}
\hline Test conducted & ASTM Code & Test Result & Code Limit \\
\hline Penetration at $25^{\circ} \mathrm{C}, 0.1 \mathrm{~mm}$ & ASTM D5 & 64.7 & $60-70$ \\
Softening point $\left({ }^{\circ} \mathrm{C}\right)$ & ASTM D36 & 48.5 & $46-56$ \\
Flash point (Cleveland open cup) ${ }^{\circ} \mathrm{C}$ & ASTM D92 & 264 & Min. 232 \\
Fire point $\left(\right.$ Cleveland open cup) ${ }^{\circ} \mathrm{C}$ & ASTM D92 & 242 & Min. 232 \\
Ductility at $25^{\circ} \mathrm{C}, \mathrm{cm}$ & ASTM D113 & 116 & Min. 100 \\
Specific gravity at $25^{\circ} \mathrm{C},(\mathrm{g} / \mathrm{cc})$ & ASTM D70 & 0.98 & $0.97-1.02$ \\
Solubility in trichloroethylene, $\%$ & ASTM D2042 & 99 & Min. 99 \\
\hline
\end{tabular}


Table 3. Test Result for test on filler materials

\begin{tabular}{llll}
\hline Test & Code Used & Value & Code Limit \\
\hline Initial Setting Time of cement (minute) & BS EN 196 PART 3 & 68 & $>45$ \\
Final Setting Time of cement (minute) & BS EN 196 PART 3 & 255 & $<375$ \\
Soundness of cement (mm) & BS EN 196 PART 3 & 3.0 & $<10$ \\
Specific Gravity of cement & ASTM C188 & 3.1 & $<3.15$ \\
Specific Gravity of CBA & ASTM C188 & 2.15 & - \\
$\%$ Cement passing 0.075 mm sieve & ASTM C117 & 97 & $>90$ \\
\hline
\end{tabular}

Table 4. Result of Oxide Composition of Coal Bottom Ash

\begin{tabular}{clcl}
\hline Elements & Concentration (\%) & Elements & Concentration (\%) \\
\hline $\mathrm{SiO}_{2}$ & 48.771 & $\mathrm{P}_{2} \mathrm{O}_{5}$ & 1.223 \\
$\mathrm{Al}_{2} \mathrm{O}_{3}$ & 11.096 & $\mathrm{SO}_{3}$ & 3.969 \\
$\mathrm{CaO}$ & 22.819 & $\mathrm{Cl}$ & 0.452 \\
$\mathrm{Fe}_{2} \mathrm{O}_{3}$ & 6.7740 & $\mathrm{TiO}_{2}$ & 1.526 \\
$\mathrm{~K}_{2} \mathrm{O}$ & 1.677 & $\mathrm{Cr}_{2} \mathrm{O}_{3}$ & 0.012 \\
$\mathrm{MgO}$ & 1.356 & $\mathrm{Mn}_{2} \mathrm{O}_{3}$ & 0.144 \\
$\mathrm{Na}_{2} \mathrm{O}$ & 3.0 & $\mathrm{SrO}$ & 0.175 \\
\hline
\end{tabular}

\subsubsection{Particle Size Distribution of Aggregates}

The gradation curves for the fine and coarse aggregates are as shown in Fig. 1. The Figure shows that the aggregates gradations satisfy the requirement for ASTM D3515 code limits, thus, suitable for use in asphalt concrete production.

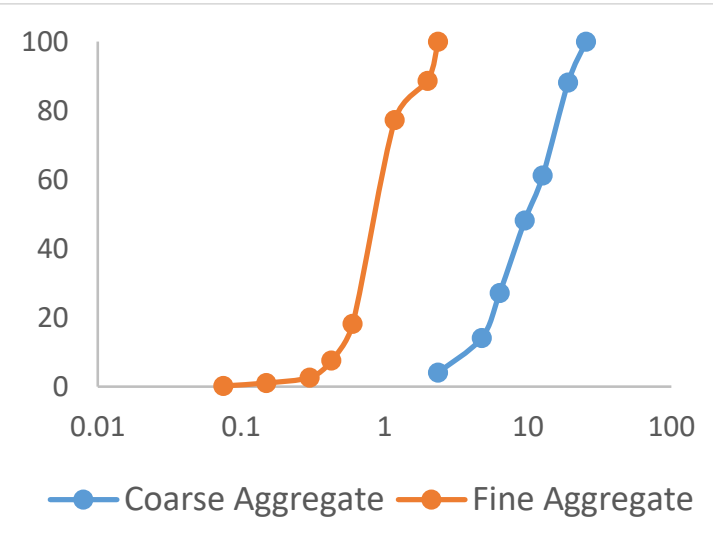

Fig. 1: Particle size distribution for fine and coarse aggregate

\subsection{MARSHALL TEST}

The specimens were prepared in accordance with Asphalt Institute (1997) (Institute, 1997) recommendations. A total of thirty (30) specimens were prepared and each specimen weighs $1200 \mathrm{~g}, 101.5 \mathrm{~mm}$ diameter and $63.5 \mathrm{~mm}$ height and heavy traffic situation was simulated by compacting each specimen with 75 hammer blows on its top and bottom sides. The sample bulk specific gravity was determined following the ASTM D6927-15. The specimens were tested for Marshall Stability and Marshall flow using the Marshall test method following the ASTM D6927 -15 The volumetric tests conducted include Bulk $\operatorname{density}\left(G_{m b}\right)$, void in mineral aggregate (VMA), void in the mix (VIM) and voids filled with bitumen (VFB). Theoretical Maximum Specific Gravity of the Mix $\left(G_{m m}\right)$ were determined using ASTM D2041-11 and Bulk Specific
Gravity $\left(G_{m b}\right)$ using ASTM D1188-96 (Papagiannakis and Masad, 2017). Void in the Mix (VIM) was used estimate in accordance with ASTM D3203-17.

The optimum bitumen content (OBC) was determined based on the marshal test method of testing HMA samples. In view of this, 15 samples of HMA with $100 \%$ cement mineral filler (control) at varying bitumen contents of 5.0,5.5, 6.0, 6.5 and $7 \%$ were prepared in accordance with asphalt institute and Nigeria General Specification for Road and Bridges (NGSRB) specifications. After which, the Marshal stability-flow and the volumetric properties such as; voids filled with bitumen (VFB), bulk density void in mineral aggregate (VMA) and void in the mix (VIM) were determined. The OBC was obtained as the average binder content for maximum density, maximum stability and specified percent air voids in the total mix. This procedure was repeated to prepare other samples with various percentage replacements of PC with CBA. The level of replacement considered ranges from $15 \%-35 \%$ at an interval of $5 \%$ and all HMA samples were prepared using the OBC obtained.

\subsubsection{Optimum Binder Content (OBC)}

The OBC was calculated based on the average of bitumen contents obtained at maximum stability, maximum bulk gravity and median percentage of air void in the mix as specified by Asphalt Institute in 1997. Table 5 show the result obtained for the specimen with $100 \%$ PC (control) as filler material. Based on the results obtained it can be seen from the table that the maximum stability and Bulk specific gravity were both obtained at $5.5 \%$ bitumen content. The bitumen content for the median percentage of air void in the mix was determined as $5.3 \%$. Hence, the OBC was found to be $5.43 \%$ but approximated to $5.5 \%$ as presented in table 6 . 
Table 5. Summary of the Marshall Test results for control specimens (0\% CBA Replacement)

\begin{tabular}{ccccccc}
\hline $\begin{array}{c}\text { Bitumen } \\
\text { content (\%) }\end{array}$ & $\begin{array}{c}\text { Stability } \\
\mathbf{( K N )}\end{array}$ & Flow $(\mathbf{m m})$ & $\begin{array}{c}\text { Bulk specific gravity } \\
\mathbf{( G )}(\mathbf{g} / \mathbf{c m} 3)\end{array}$ & $\begin{array}{c}\text { VIM } \\
\mathbf{( \% )}\end{array}$ & $\begin{array}{c}\text { VMA } \\
\mathbf{( \% )}\end{array}$ & $\begin{array}{c}\text { VFB } \\
\mathbf{( \% )}\end{array}$ \\
5.0 & 4.05 & 1.95 & 2.34 & 3.63 & 15.93 & 77.21 \\
5.5 & 4.30 & 3.15 & 2.39 & 4.47 & 17.78 & 74.86 \\
6.0 & 3.95 & 3.05 & 2.35 & 4.92 & 19.26 & 74.45 \\
6.5 & 3.90 & 3.65 & 2.33 & 3.72 & 19.62 & 81.04 \\
7.0 & 3.25 & 3.50 & 2.30 & 4.20 & 20.70 & 79.71 \\
\hline
\end{tabular}

Table 6. Determination of OBC using control mix

\begin{tabular}{ll}
\hline Test property & Bitumen content $(\%)$ \\
\hline Max. stability $(\mathrm{kN})$ & 5.5 \\
Max. bulk density $(\mathrm{g} / \mathrm{cm} 3)$ & 5.5 \\
Median \% air voids & 5.3 \\
\hline $\mathrm{OBC}=(5.5+5.5+5.3) / 3=5.43 \approx 5.5$ \\
\hline
\end{tabular}

\section{Results ANd Discussion}

\subsection{MARShall Test Results of Hot mixed Asphalt} at Varying Percentage Replacement of Cement WITH CBA AT OBC OF $5.5 \%$

The results for the Marshal stability-flow and the volumetric analysis at varying percentage replacement of cement with CBA are presented in Figures.

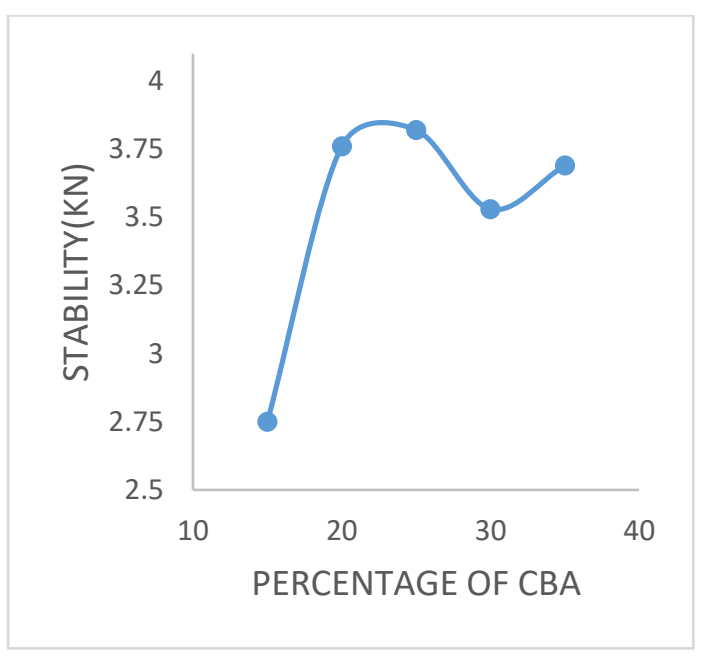

Fig. 2: Stability against percentage replacement with CBA

Stability is an indication of the strength a compacted material. From Fig.2, it can be deduced that the maximum stability is $3.85 \mathrm{KN}$ at $25 \%$ cement replacement with CBA. A reduction was noted in comparison with the control specimen ( $100 \%$ cement content) having $4.3 \mathrm{KN}$ at an OBC of $5.5 \%$. The reduction in the stability could be as a result of the higher content of fine particles (CBA) in the mix which cushioned the larger particles and weaken the aggregate skeleton packing. Similar findings were reported in the work of Antunes et al, 2015 and Shuaibu et $a l, 2020$. However, the stability value of the HMA satisfies the minimum value of $3.5 \mathrm{kN}$ for use in the wearing course as prescribed by NGSRB.

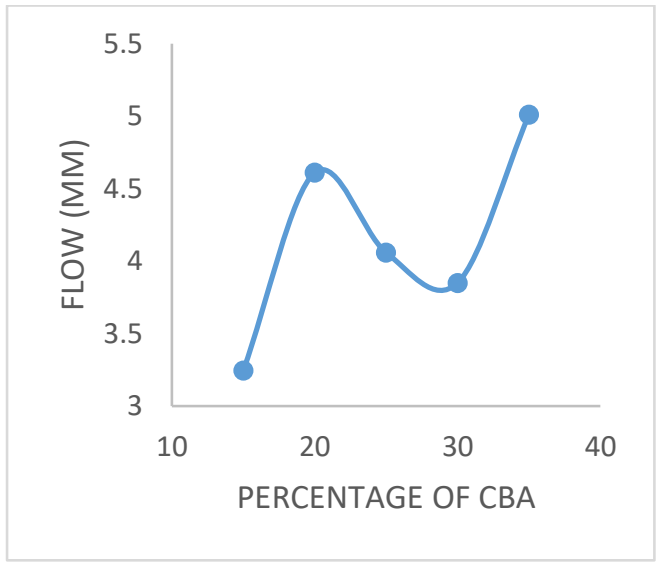

Fig. 3: Flow $(\mathrm{mm})$ against percentage replacement with CBA

Flow is a measure of deformation in the diameter of the test sample during the marshal stability test. From Figure 3 above, it can be observed the flow value increased with an increase in the percentage of CBA of up to $20 \%$ and subsequently dropped then rises with a further increase in CBA content to $35 \%$. However, all the flow values obtained for various proportions of $\mathrm{CBA}$ are within the range of $2-4 \mathrm{~mm}$ for wearing course as specified by NGSRB.

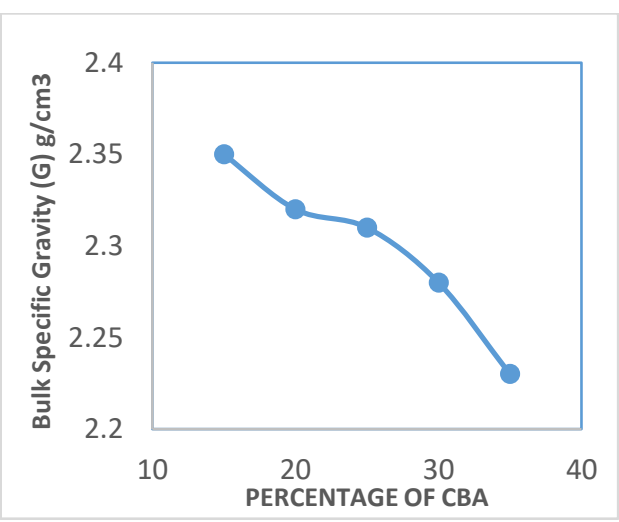

Fig. 4: Specific gravity against percentage replacement with CBA

Fig. 4 present the results for the bulk specific gravity at varying percentages of $\mathrm{CBA}$ content, from the figure it can be seen that the specific gravity of the HMA mix decreased steadily with an increase in the CBA percentage replacement of cement. This trend could be as result of the lower specific gravity of the $\mathrm{CBA}$ as compared to the specific gravity of cement. 


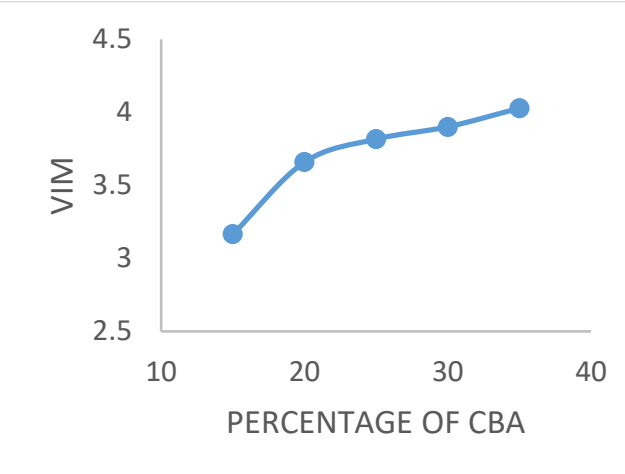

Fig. 5: Void in mix (VIM) against percentage replacement with CBA

The result for the volumetric analysis of void in mix (VIM) is presented in figure 5. As shown in figure 5, the percent air void in mix (VIM) steadily increases with an increase in Coal bottom ash contents. Base on the results obtained all the samples satisfied the required limit of $3-5 \%$ as specified in the NGSRB.

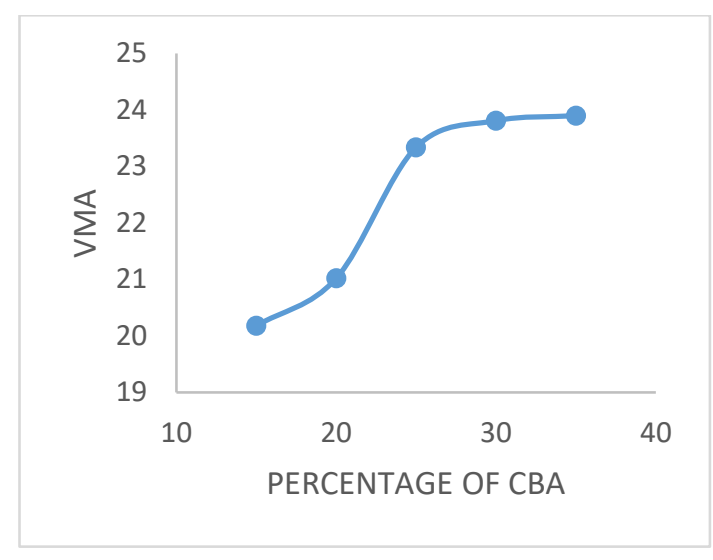

Fig. 6: VMA against percentage replacement with CBA

The voids in the mineral aggregate (VMA) is the percentage of void space between the aggregate particles in a compacted HMA mixture content (O'Flaherty, 2002). It can be observed from Figure 6 that when the percentage replacement of CBA increases, the void in mineral aggregate increases, this could be due to the excess of CBA which the bitumen can coat sufficiently and bind with the aggregate.

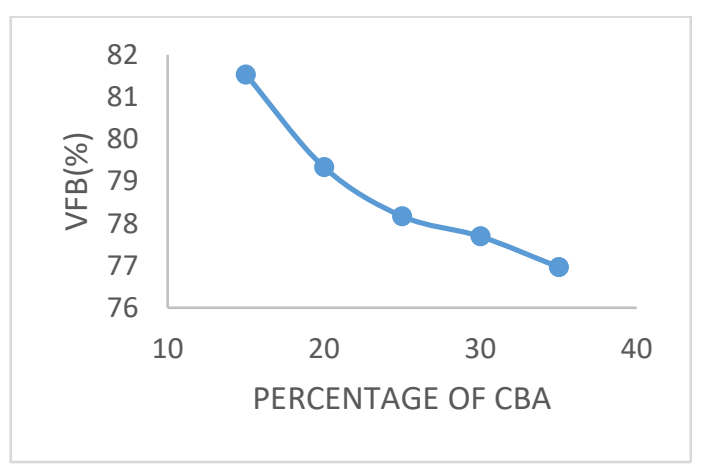

Fig. 7: Void filled with bitumen (VFB) against percentage replacement with CBA
Fig. 7 presents the relationship between the percent VFB and percentage replacement with CBA. It can be observed that the VFB steadily decreases with increasing CBA contents. However, the results obtained at the various percentage replacements satisfy the requirement for the Nigerian General Specifications for Roads and Bridges (NGSRB) of $75-82 \%$.

\section{Conclusion}

This study evaluates the properties of hot mix asphalt produced with coal bottom ash as filler material. Based on the experimental results, the following conclusions can be drawn;

1. The chemical oxide composition test revealed that the CBA is of class $C$ pozzolana.

2. The aggregate encompasses well-graded materials which satisfy the requirements and specifications provided by the relevant codes used for strength and specific gravity.

3. The $\mathrm{OBC}$ for the stability of the mix design was obtained to be $5.5 \%$.

4. The highest value of marshal stability of $3.86 \mathrm{KN}$ and a corresponding flow of $4.61 \mathrm{~mm}$ were recorded at $25 \%$ cement replacement with coal bottom ash at $5.5 \%$ optimum bitumen content. Hence up to $25 \%$ of cement can be replaced with CBA as mineral filler in the HMA production.

\section{REFERENCES}

American Association of State Highway and Transport Officials (AASHTO) (2000) Standard Specification for Transportation Materials and Methods for Sampling and Testing Part 1 \& 2 . Twentieth edition. American Association of State Highway and Transportation Officials. Washington

American Association of State Highway and Transportation Officials (AASHTO) (2000). "AASHTO Provisional Standards". American Association of State Highway and Transportation Officials. Washington.

Antunes, V., Freire, A., Quaresma, L., \& Micaelo, R. (2015). Influence of the geometrical and physical properties of filler in the fillerbitumen interaction. Construction and Building Materials, vol. 76, pp: 322-329.

Arabani, M., \& Tahami, S. A. (2017). Assessment of mechanical properties of rice husk ash modified asphalt mixture. Construction and Building Materials, 149, 350-358.

Armada Bras, A., \& Faustino, P. (2016). Repair mortars and new concretes with coal bottom and biomass ashes using rheological optimisation. International Journal of Environmental Research, 10(2), 203-216.

ASTM D946. (2020). Standard Specification for Penetration-Graded Asphalt Binder for Use in Pavement Construction, ASTM International, West Conshohocken, PA.

ASTM D5. (1997). Standard Test Method for Penetration of Bituminous Materials, ASTM International, West Conshohocken, PA.

ASTM D36. (2000). Standard Test Method for Softening Point of Bitumen (Ring-and-Ball Apparatus), ASTM International, West Conshohocken, PA.

ASTM D92. (2002). Standard Test Method for Flash and Fire Points by Cleveland Open Cup, ASTM International, West Conshohocken, PA.

ASTM D113. (2017). Standard Test Method for Ductility of Asphalt Materials, ASTM International, West Conshohocken, PA. 
ASTM D70. (2003). Standard Test Method for Specific Gravity and Density of Semi-Solid Bituminous Materials (Pycnometer Method), ASTM International, West Conshohocken, PA.

ASTM D2041. (2011). Standard test method for theoretical maximum specific gravity and density of bituminous paving mixtures: ASTM International West Conshohocken, PA, USA.

ASTM D2042. (2015). Standard Test Method for Solubility of Asphalt Materials in Trichloroethylene, ASTM International, West Conshohocken, PA.

ASTM D3203. (2017). Standard Test Method for Percent Air Voids in Compacted Asphalt Mixtures: ASTM International West Conshohocken, PA, USA.

British Standard Institution. (1990) BS 812-110: Testing aggregates Methods for determination of aggregate crushing value (ACV).

British Standard Institution. (1990) BS 812-112: Testing aggregates Method for determination of aggregate impact value (AIV).

ASTM C127. (2015). Standard Test Method for Relative Density (Specific Gravity) and Absorption of Coarse Aggregate, ASTM International, West Conshohocken, PA.

ASTM C128. (2015). Standard Test Method for Relative Density (Specific Gravity) and Absorption of Fine Aggregate, ASTM International, West Conshohocken, PA.

British Standard Institution. (1985) BS 812-103.1: Testing aggregates. Method for determination of particle size distribution. Sieve tests.

British Standard Institution. (2005) BS EN 196-3: Methods of testing cement. Determination of setting times and soundness.

ASTM C188. (2017). Standard Test Method for Density of Hydraulic Cement, ASTM International, West Conshohocken, PA.

ASTM C311 / C311M. (2018). Standard Test Methods for Sampling and Testing Fly Ash or Natural Pozzolans for Use in PortlandCement Concrete, ASTM International, West Conshohocken, PA.

ASTM C618. (2019) Standard Specification for Coal Fly Ash and Raw or Calcined Natural Pozzolan for Use in Concrete, ASTM International, West Conshohocken, PA.

Asphalt Institute. (1997). Mix Design Methods for Asphalt, Manual Series No. 2 (MS-02). The Asphalt Institute. Lexington, KY.

Federal Ministry of Works \& Housing - FMWH. (1997). General Specifications for Roads and Bridge. Federal Ministry of Works \& Housing Abuja, Nigeria.

ASTM D6927. (2015). Standard Test Method for Marshall Stability and Flow of Asphalt Mixtures. ASTM International: West Conshohocken, PA, USA.

.AUSTROADS, (1998). Treatment of cracks in flexible pavements. Pavement Work Tips No. 8 Book of Highway Engineering. American Association of State Highway and Transportation Officials. Washington.

BS EN, 197-1, (2000). Cement-Part 1 Composition, specifications and conformity criteria for common cements.

Branger, F., Ponssard, J.-P., Sartor, O., \& Sato, M. (2015). EU ETS, free allocations, and activity level thresholds: the devil lies in the details. Journal of the Association of Environmental and Resource Economists, vol. 2, No. 3, pp: 401-437.

Colonna P et al. (2012) "Procedia - Social and Behavioral Sciences, vol. 5, No. 3, pp: 962-972 California

Ferronato, N., \& Torretta, V. (2019). Waste mismanagement in developing countries: A review of global issues. International journal of environmental research and public health, vol. 16, No. 6, pp. 1060-1073.

Frías, M., De Rojas, M. S., García, R., Valdés, A. J., Medina, C. J. C., \& Composites, C. (2012). Effect of activated coal mining wastes on the properties of blended cement. vol.34, No.5, pp: 678-683.

Huang, W. (1990). The Use of Bottom Ash in Highway Embankments, Subgrades, and Subbases. Publication FHWA/IN/JHRP-90/04-1. Joint Highway Research Project, Indiana Department of Transportation and Purdue University, West Lafayette, Indiana, https//doi.org/10.5703/1288284314179
Institute, A. (1997). Mix design methods for asphalt concrete and other hot-mix types Asphalt Institute.

Jaturapitakkul, C., \& Cheerarot, R. (2003). Development of bottom ash as pozzolanic material. Journal of Materials in Civil Engineering, vol. 15, No. 1, pp: 48-53.

Khan, R. A., \& Ganesh, A. (2016). The effect of coal bottom ash (CBA) on mechanical and durability characteristics of concrete. Journal of building materials and structures, vol. 3, No. 1, pp: 31-42.

Kieran (2005). Effect of Mineral Filler Type and Content on Properties of Asphalt Concrete in Hot Mix Asphalt. International Journal of Research in Engineering and Technology, vol. 5.

Mistry, R., \& Roy, T. K. (2016). Effect of using fly ash as alternative filler in hot mix asphalt. Perspectives in Science, vol. 8, pp: 307-309.

Modarres, A., \& Rahmanzadeh, M. (2014). Application of coal waste powder as filler in hot mix asphalt. Construction and Building Materials, vol. 66, pp: 476-483.

Mohammed, S. A., \& Karim, M. R. (2017). Application of coal bottom ash as aggregate replacement in highway embankment, acoustic absorbing wall and asphalt mixtures. Paper presented at the IOP Conference Series Materials Science and Engineering.

Movilla-Quesada, D., Muñoz, O., Raposeiras, A., Castro-Fresno, D. J. C., \& Materials, B. (2018). Thermal suspectability analysis of the reuse of fly ash from cellulose industry as contribution filler in bituminous mixtures. Vol. 160, pp: 268-277.

O'Flaherty, CA. 2002. Highways: The Location, Design, Construction and Maintenance of Pavements (4th edition). pp. 332-340, Jordan Hill-Butterworth-Heinemann, Oxford, U.K.

Papagiannakis, A. T., \& Masad, E. A. (2017). Pavement design and materials John Wiley \& Sons.

Rengarasu, T., Juzaafi, M., Bandara, W., \& Jegatheesan, N. (2019). Suitability of Coal Bottom Ash and Carbonized Rice Husk in Hot Mix Asphalt. Journal of the Eastern Asia Society for Transportation Studies, vol. 13, pp: 1630-1640.

Shuaibu, A. A. H. S. Otuoze, A. Mohammed and M. A. Lateef (2019): "Properties of Asphalt concrete containing Waste foundry Sand (WFS) as Filler material", ARID Zone Journal of engineering, Technology \& Environment (AZOJETE), Faculty of Engineering, University of Maiduguri, Maiduguri, Nigeria., September 2019. Vol. 15(3) 662-677.

Shuaibu, A. A., Umar, A. M., Otuoze, H. S., Mohammed, A., \& Abba, A. M. (2020). Optimum Portland Cement-Guinea Corn Husk Ash Blend as Filler in Hot Mix Asphalt. Covenant Journal of Engineering Technology (CJET), Covenant University, Ota, Ogun State, Vol.4(2), December, 2020 56-66. Singh, M., \& Siddique, R. (2013). Effect of coal bottom ash as partial replacement of sand on properties of concrete. Resources, conservation and recycling, vol. 72, pp: 20-32.

Singh, M., \& Siddique, R. (2016). Effect of coal bottom ash as partial replacement of sand on workability and strength properties of concrete. Journal of Cleaner Production, vol. 11, No. 2, pp: 620-630.

Singh, N., \& Bhardwaj, A. (2020). Reviewing the role of coal bottom ash as an alternative of cement. Construction and Building Materials, vol. 23, No. 3, pp: 117276.

Standard, A. (2004). Test Designation C 131, ASTM D 5; ASTM D 36; ASTM D 113. ASTM D 1559. Annual Book of ASTM Standards (Section 04) West Conshohocken, Philadelphia, USA.

Tahami, S. A., Arabani, M., \& Mirhosseini, A. F. (2018). Usage of two biomass ashes as filler in hot mix asphalt. Construction and Building Materials, vol. 170, pp: 547-556.

Tenza-Abril, A. J., Saval, J. M., \& Cuenca, A. (2015). Using sewagesludge ash as filler in bituminous mixes. Journal of Materials in Civil Engineering, 27(4), 04014141.

Thanaya, I., Forth, P., \& Zoorob, S. (2006). Utilisation of coal ashes in hot and on cold bituminous mixtures. Paper presented at the Int. Coal Ash Technology Conf. 